\title{
GAGASAN PENGATURAN KODIFIKASI DAN UNIFIKASI PERATURAN PERUBAHAN DAN PERATURAN OMNIBUS LAW
}

\author{
Edy Sujendro \\ Kanwil Kemenkumham Jawa Tengah, Semarang \\ edy.sujendro@gmail.com
}

\begin{abstract}
Abstrak
Penelitian ini bertujuan untuk mengkaji dan menganalisa mengapa dibutuhkan pengaturan kodifikasi dan unifikasi peraturan perubahan dan peraturan omnibus law serta bagaimana pengaturan kodifikasi dan unifikasi peraturan perubahan dan peraturan omnibus law. Metode penelitian yang dipergunakan diantaranya adalah tipe penelitian yuridis normatif, dengan pendekatan perundang - undangan dan pendekatan konsep, spesifikasi penelitan diskriptif analitis, pengumpulan data dengan studi kepustakaan, dan analis data kualitatif. Penelitian ini menunjukkan bahwa Bentuk peraturan perubahan dan peraturan yang menggunakan metode omnibus law menyulitkan masyarakat untuk memahami secara lengkap karena mengharuskan masyarakat membuka banyak naskah. gagasan pengaturan kodifikasi dan unifikasi dalam 1 (satu) naskah peraturan perubahan dan peraturan yang menggunakan metode omnibus law sangat memungkinkan untuk dapat diterapkan dengan menggunakan Peraturan Presiden sesuai kewenangan yang diberikan dalam Pasal 64 UU 12/2011 tentang Pembentukan Peraturan Perundang-undangan.
\end{abstract}

Kata kunci : Kodifikasi; Unifikasi; Peraturan; Perubahan; Omnibus Law 


\title{
REVIEW CODIFICATION AND UNIFICATION REGULATIONS OF AMENDMENT AND OMNIBUS LAW REGULATIONS
}

\begin{abstract}
This study aims to review and analyze why it is necessary to regulate the codification and unification of amendments rules and omnibus law regulations and how to codify and unify rules of change and rules of omnibus law. The research method used includes the juridical normative research type, with a statutory approach and a conceptual approach, descriptive analytical research specifications, data collection using library research, and qualitative data analysis. This research shows that the form of amendments and regulations that use the omnibus law method makes it difficult for people to fully understand because it requires people to open many texts. The idea of regulating codification and unification in 1 (one) text of amendment regulations and regulations using the omnibus law method is very possible to be applied using a Presidential Regulation in accordance with the authority given in Article 64 of Law 12/2011.
\end{abstract}

Keywords: Codification; Unification; Regulations; Amendement;Omnibus Law 


\section{A. PENDAHULUAN}

Peraturan Perundang-undangan merupakan sumber hukum dari tata nilai yang dipercaya masyarakat sebagai suatu sistem penataan kehidupan pribadi, bermasyarakat, berbangsa, dan bernegara. Makanya dengan kata lain hukum sebagai acuan pembaruan masyarakat sebagaimana konsep Roscoe Pound dalam law as a tool of social engineering. ${ }^{1}$ Untuk itu, pemahaman hukum dari suatu peraturan perundang-undangan harus dapat dengan mudah dipahami oleh seluruh penduduk indonesia.

Hal ini termasuk peraturan yang berbentuk perubahan dan omnibus law yang mengharuskan masyarakat indonesia membuka undang-undang pokoknya dan menyandingkan undang-undang perubahannya. Hal ini akan membuat masyarakat harus memegang:

a. 2 (dua) peraturan (peraturan pokok dan perubahannya) jika perubahan baru sekali;

b. 3 (tiga) peraturan (peraturan pokok dan 2 perubahannya jika perubahan kedua;

c. 4 (empat) peraturan (peraturan pokok dan 3 perubahannya jika perubahan ketiga;

d. dan seterusnya.

Sedangkan pada metode omnibus law, masyarakat Indonesia jika ingin memahaminya butuh lebih banyak lagi memegang peraturan perundang-undangan terkait baik yang terdampak berupa perubahan dan/atau pencabutan atau penghapusan. Undang-Undang Cipta Kerja ${ }^{2}$ misalnya, banyak undang-undang yang terdampak. Dengan kata lain jika masyarakat ingin mengetahui secara utuh semangat Cipta Kerja yang ada dalam Undang-Undang Cipta Kerja harus mempersandingkan banyak dokumen peraturan termasuk perubahannya.

Untuk itu, peraturan yang berbentuk perubahan dan omnibus law perlu dilakukan kodifikasi dan unifikasi untuk memberikan kemudahan pemahaman bagi masyarakat dengan tidak memegang terlalu banyak dokumen hukum suatu peraturan perubahan dan peraturan yang menggunakan metode omnibus law. Keunggulan

\footnotetext{
${ }^{1}$ Roscoe Pound and Marshall L DeRosa, An Introduction to the Philosophy of Law (Yale University Press, 1954), x.

2 Dalam UU 11 Tahun 2020 tentang Cipta Kerja dapat dilihat bahwa banyak undang-undang yang terdampak sehingga masyarakat harus menyandingkan peraturan yanng terdampak untuk memahami secara komprehensif undang-undang tersebut.
} 
e-ISSN : 2621-4105

metode omnibus law adalah kepraktisan mengoreksi banyak regulasi bermasalah. Meningkatkan kecepatan dalam penyusunan undang-undang, dengan menyusun sebuah omnibus law sekaligus mengoreksi undang-undang bermasalah yang sedang berlaku. Pendekatan omnibus law juga bisa menjadi solusi atas tumpang tindih regulasi di Indonesia baik dalam hubungan hierarki sejajar horizontal maupun vertikal. Dalam prakteknya penyusunan omnibus law berbiaya mahal dan tidak sederhana karena substansinya pasti multi sektor dan dipersiapkan untuk super power. Namun nyatanya dengan metode omnibus law dapat mengatasi konflik peraturan perundang-undangan secara cepat, efektif, dan efisien. ${ }^{3}$

Kajian kebutuhan kodifikasi dan unifikasi telah diulas pada beberapa artikel antara lain oleh Merdiansa Paputungan (2018) yang mengkaji tentang Unifikasi Hukum Acara Pengujian Seluruh Peraturan Perundang-Undangan, dimana kajian ini dilatar belakangi tidak seragamnya mekanisme hukum acara di antara Mahkamah Agung dan Mahkamah Konstitusi. Hal ini menyisakan permasalahan sehingga diperlukan unifikasi hukum acara pengujian seluruh peraturan perundang-undangan merupakan solusi yang paling mungkin dilakukan. ${ }^{4}$ Meskipun kajian ini membuka wawasan terkait kebutuhan seragamnya mekanisme hukum acara di antara Mahkamah Agung dan Mahkamah Konstitusi, akan tetapi penelitian ini hanya pada mekanisme beracara.

Kajian Dewa Nyoman Rai Asmara Putra (2018) fokus membahasa tentang Asas Integrasi Dalam Undang-Undang Kepailitan Versus Cita-Cita Kodifikasi Dan Unifikasi Hukum Acara Perdata, dimana kajian ini dilatarbelakangi hukum acara perdata semakin tersebar bahkan parsial, dalam peraturan perundang-undangan sehingga perlu dilakukan kodifikasi dan unifikasi hukum acara perdata nasional. ${ }^{5}$ Meskipun kajian ini memberikan gambaran terkait kebutuhan kodifikasi dan unifikasi Hukum Acara Perdata, akan tetapi penelitian ini hanya fokus pada permasalahan parsial dalam Hukum Acara Perdata.

\footnotetext{
${ }^{3}$ Muhamad Azhar, 'Unifikasi Hukum Acara Pengujian Seluruh Peraturan Perundang-Undangan', Adminitrative Law \& Governance Journal 2(1), 2019, 177. https://doi.org/10.14710/alj.v2i1.170-178

${ }^{4}$ Merdiansa Paputungan, 'Unifikasi Hukum Acara Pengujian Seluruh Peraturan Perundang-Undangan', Al-Qisth Law Review 1(1), 2018, 23.

${ }^{5}$ Dewa Nyoman Rai Asmara Putra, ‘Asas Integrasi Dalam Undang-Undang Kepailitan Versus Cita-Cita Kodifikasi Dan Unifikasi Hukum Acara Perdata', ADHAPER: Jurnal Hukum Acara Perdata 4(1), 2018, 159-78.
} 
Sedangkan Eza Aulia dan Dara Quthni Effida mengkaji tentang Kodifikasi Hukum Islam Di Indonesia Dalam Perspektif Kepastian Hukum, dimana kajian ini dilatarbelakangi hukum islam yang telah menjadi hukum positif Indonesia saat ini, hanya hukum islam yang terkait dengan hukum privat, yaitu ubudiyah dan mu'amalah. Sedangkan yang berhubungan dengan hukum publik Islam sampai saat ini masih menjadi hukum yang dicita-citakan. Untuk itu Kodifikasi hukum islam dapat dikatakan sebagai suatu kebutuhan hukum. ${ }^{6}$ Meskipun kajian ini memberikan gambaran terkait kebutuhan Kodifikasi Hukum Islam, akan tetapi penelitian ini hanya fokus pada Hukum Islam.

Ketiga kajian kebutuhan kodifikasi dan unifikasi tersebut masih bersifat pada peraturan tertentu, sehingga belum ada kajian kebutuhan kodifikasi dan unifikasi peraturan yang umum (berlaku untuk semua peraturan) dibutuhkan masyarakat yakni terhadap peraturan perubahan dan peraturan yang menggunakan metode omnibus law untuk memahami hukum yang terpisah karena terdiri dari banyak dokumen hukum peraturan perubahan dan peraturan yang menggunakan metode omnibus law.

Padahal, tidak adanya kodifikasi dan unifikasi peraturan pokok, Peraturan Perubahan dan Peraturan metode Omnibus Law berpotensi menjadikan permasalahan yakni kesulitan pemahaman bagi masyarakat. Mengingat harus memahami banyak dokumen peraturan tersebut. Potensi masalah yang memungkinkan terjadi adalah sebagai berikut:

1. Masyarakat akan kesulitan memahami;

2. Masyarakat akan mudah terpengaruh informasi yang tidak tepat terkait peraturan perubahan maupun omnibus law;

3. Terjadi buruk sangka antara masyarakat dan pembentuk peraturan;

4. Penyalahgunaan wewenang; atau

5. Potensi lain yang menghambat pembentukan

Dengan demikian, selain melengkapi kajian sebelumnya mengenai kebutuhan kodifikasi dan unifikasi peraturan, penulisan "Gagasan Pengaturan Kodifikasi dan Unifikasi Peraturan Perubahan dan Peraturan Omnibus Law”, juga untuk memberikan kemudahan masyarakat memahami tanpa mengurangi substansi dalam

${ }^{6}$ Eza Aulia, Dara Quthni Effida, 'Kodifikasi Hukum Islam Di Indonesia Dalam Perspektif Kepastian Hukum', Ius Civile: Refleksi Penegakan Hukum Dan Keadilan 2(2), 2018. 
suatu kodifikasi dan unifikasi peraturan pokok dan perubahannya termasuk jika terdampak pada peraturan yang menggunakan metode omnibus law. Penelitian ini bertujuan untuk mengkaji dan menganalisa mengapa dibutuhkan pengaturan kodifikasi dan unifikasi peraturan perubahan dan peraturan omnibus law serta bagaimana pengaturan kodifikasi dan unifikasi peraturan perubahan dan peraturan omnibus law.

\section{B. PERMASALAHAN}

Dalam penulisan ini, membatasi mengenai gagasan terhadap pengaturan kodifikasi dan unifikasi peraturan perubahan dan peraturan Omnibus Law.

1. Mengapa dibutuhkan pengaturan kodifikasi dan unifikasi peraturan perubahan dan peraturan omnibus law;

2. Bagaimana pengaturan kodifikasi dan unifikasi peraturan perubahan dan peraturan omnibus law;

\section{METODE PENELITIAN}

\section{Tipe Penelitian}

Penelitian ini merupakan penelitian yuridis normatif. Sebagaimana dikutip Mulyani dan Muryati ${ }^{7}$ dari Ibrahim ${ }^{8}$ penelitian yuridis normatif berfokus untuk kajian penerapan kaedah atau norma hukum positif. Tipe penelitian ini digunakan mengingat obyek penelitiannya adalah memunculkan gagasan atas adanya kekosongan hukum terhadap pengaturan kodifikasi dan unifikasi peraturan perubahan dan peraturan metode omnibus law.

\section{Metode Pendekatan}

Metode pendekatan dalam penelitian ini menggunakan 3 (tiga) aspek yaitu: a. pendekatan perundang-undangan digunakan untuk meneliti aturan terkait pembentukan peraturan perundang-undangan yang sampai saat ini belum diatur mengenai pengaturan kodifikasi dan unifikasi peraturan perubahan dan peraturan metode omnibus law;

${ }^{7}$ Tri Mulyani, Dewi Tuti Muryati, 'Analisis Yuridis Mengenai Sistem Zonasi Dalam Penerimaan Peserta Didik Baru’, Jurnal Usm Law Review 3(1), 2020, 34-58. DOI: http://dx.doi.org/10.26623/julr.v3i1.2118 2005.

${ }^{8}$ Johnny Ibrahim, 'Teori Dan Metode Penelitian Hukum Normatif', Malang: Bayumedia Publishing, 
b. pendekatan analitis digunakan untuk mengetahui teori, peraturan, dan kebutuhan hukum pengaturan kodifikasi dan unifikasi peraturan perubahan dan peraturan metode omnibus law; dan

c. pendekatan konsep gagasan digunakan untuk menawarkan kebaruan atas pengaturan dan bentuk kodifikasi dan unifikasi peraturan perubahan dan peraturan metode omnibus law;

\section{Spesifikasi Penelitian}

Spesifikasi penelitian yang akan dipergunakan adalah diskriptif analitis. Sebagaimana dikutip Mulyani dan Muryati ${ }^{9}$ dari Bambang $^{10}$, diskriptif analitis yaitu menggambarkan peraturan perundang-undangan yang berlaku sebagai hukum positif dikaitkan dengan teori hukum dan praktek pelaksanaan hukum positif dalam masyarakat.

Dengan demikian, untuk mendapatkan gambaran yang jelas mengenai gagasan atas kebutuhan hukum atas pengaturan dan bentuk kodifikasi dan unifikasi peraturan perubahan dan peraturan metode omnibus law, maka dalam penelitian ini akan diuraikan hasil-hasil penelitian sesuai dengan permasalahan dan tujuan yang akan dicapai serta menganalisisnya dari segi peraturan yang berlaku.

\section{Teknik Pengumpulan Data}

Teknik pengumpulan data dalam penelitian ini adalah menggunakan teknik studi pustaka (collecting by library). Sebagaimana dikutip Setiyawan dan Mahmud $^{11}$ dari Ibrahim ${ }^{12}$, Pengumpulan bahan hukum primer, bahan hukum sekunder dan bahan hukum tersier diinventarisasi dan diklasifikasi dengan menyesuaikan masalah yang dibahas. Bahan hukum yang berhubungan dengan masalah yang dibahas dipaparkan, disistematisasi, kemudian dianalisis untuk menginterpretasikan hukum yang berlaku yang kemudian memunculkan gagasan yang akan ditawarkan.

\footnotetext{
${ }^{9}$ Mulyani and Muryati.

${ }^{10}$ Bambang Sunggono, 'Metode Penelitian Hukum', Radja Grafindo Persada, Jakarta, 1997.

${ }^{11}$ Wahyu Beny Mukti Setiyawan And Hadi Mahmud, 'Menggagas Model Restorative Justice Terhadap Tindak Pidana Marital Rape Dalam Membentuk Perlindungan Terhadap Perempuan Yang Sesuai Dengan Norma Hukum Di Indonesia', Jurnal Ius Constituendum, 3(1), 2018, 68-82.

${ }^{12}$ Ibrahim.
} 
e-ISSN : 2621-4105

\section{PEMBAHASAN}

\section{Analisis Teori}

\section{a. Kodifikasi dan Unifikasi}

Pengertian Kodifikasi menurut Umar Said ${ }^{13}$, sebagaimana yang dikutip Sugiantari ${ }^{14}$, adalah membukukan hukum sejenis, secara lengkap, sistematis menjadi satu dalam satu kitab Undang-Undang, hal itu misalnya: Hukum Pidana dalam Kitab Undang-Undang Hukum Pidana, hukum perdata dalam Kitab Undang-Undang Hukum Perdata, hukum dagang dalam Kitab UndangUndang Hukum Dagang. Sedangkan Unifikasi adalah penyatuan hukum yang berlaku secara nasional atau penyatuan pemberlakuan hukum secara nasional.

Kodifikasi dan unifikasi inilah yang menjadi formula yang tepat atas format peraturan yang berbentuk perubahan atau metode omnibus law yang mengharuskan masyarakat memegang banyak dokumen peraturan untuk memahaminya.

\section{b. Kedaulatan Hukum}

Teori Kedaulatan Hukum menurut Krabbe yaitu dijelaskan bahwa kekuasaan pemerintah bukanlah dari Tuhan, raja, atau negara. Akan tetapi Pemerintah mendapatkan kekuasaannya berdasarkan atas hukum. Pemilik daulat sebenarnya adalah hukum, baik pemerintah maupun rakyat memperoleh kekuasaan dari hukum ${ }^{15}$.

Rakyat yang memperoleh kekuasaan dari hukum sangat disayangkan apabila tidak dapat memahami hukum dari peraturan perundang-undangan yang berbentuk perubahan maupun yang menggunakan metode omnibus law.

\section{c. Negara Hukum}

Konsep Negara hukum menurut Frederich Julius Stahl memiliki empat unsur yaitu ${ }^{16}$ :

1) Hak-hak Dasar Manusia.

2) Pembagian Kekuasaan.

\footnotetext{
${ }^{13}$ Umar Said, Pengantar Hukum Indonesia: Sejarah Dan Dasar-Dasar Tata Hukum Serta Politik Hukum Indonesia, Setara Press, 2009.

${ }^{14}$ Anak Agung Putu Wiwik Sugiantari, 'Perkembangan Hukum Indonesia Dalam Menciptakan Unifikasi Dan Kodifikasi Hukum', Jurnal Advokasi 5 (2), 2015.

${ }^{15}$ Cristine S T Kansil and S T Christine, 'Kansil. Ilmu Negara (Umum Dan Indonesia)', Jakarta: Pradnya Paramita, 2007.

${ }^{16}$ A Mukthie Fadjar, 'Tipe Negara Hukum', Banyumedia, Malang, 2005.
} 
3) Pemerintahan berdasarkan peraturanperaturan, dan

4) Peradilan Tata Usaha dan Perselisihan.

Hal ini berlaku pula di Indonesia yang juga merupakan negara hukum. Untuk itu masyarakat untuk mengetahui hak dasarnya dalam setiap peraturan, harus memahami secara lengkap peraturan yang telah ditetapkan. Konsep negara hukum di Indonesia sudah berubah setelah dilakukan amandemen Undang-Undang Dasar Tahun 1945. Setelah amandemen, konsep negara hukum di Indonesia bukan lagi rechtsstaat atau rule of law, melainkan Negara Hukum Indonesia. Maksud penegasan ini memiliki makna sangat penting, terutama jika dikaitkan dengan sistem hukum yang sudah ada di dunia. Konsep negara hukum rechtsstaat dan rule of law sangat berpengaruh bagi negara hukum Indonesia

\section{d. Perubahan Peraturan}

Teori mengenai perubahan peraturan, belum banyak diulas secara akademik. Akan tetapi satu-satunya yang dapat dijadikan rujukan adalah lampiran II Undang-Undang 12/2011 tentang Pembentukan Peraturan Perundang-undangan pada angka 6 - angka 9 dan angka 230 - angka 238 .

Identifikasi peraturan perubahan dapat dilakukan dari Judul dan Batang Tubuhnya:

1) Judul Peraturan Perubahan lazimnya menyebutkan kata Perubahan dengan ketentuan:

a) jika perubahan pembentukan baru pertama kali, namanya "Perubahan Atas ..."

b) jika perubahan pembentukan telah dilakukan kedua kali atau lebih, namanya "Perubahan Kedua/Ketiga/dan seterusnya..."

2) Perubahan Peraturan Perundang-undangan dilakukan dengan:

a) menyisip atau menambah materi ke dalam Peraturan Perundangundangan; atau

b) menghapus atau mengganti sebagian materi Peraturan Perundangundangan. 
3) Perubahan Peraturan Perundang-undangan dapat dilakukan terhadap:

a) seluruh atau sebagian buku, bab, bagian, paragraf, pasal, dan/atau ayat; atau

b) kata, frasa, istilah, kalimat, angka, dan/atau tanda baca.

Contoh 1:

PERATURAN DAERAH KABUPATEN JAYAPURA

NOMOR 14 TAHUN 2009

TENTANG

PERUBAHAN ATAS PERATURAN DAERAH

NOMOR 2 TAHUN 2007 TENTANG POKOK-POKOK PENGELOLAAN KEUANGAN DAERAH

Contoh 2:

\section{Pasal I}

Beberapa ketentuan dalam Undang-Undang Nomor ... Tahun ... tentang ... (Lembaran Negara Republik Indonesia Tahun ... Nomor ..., Tambahan Lembaran Negara Republik Indonesia Nomor ...) diubah sebagai berikut:

1. Ketentuan Pasal 6 diubah sehingga berbunyi sebagai berikut:

2. Ketentuan ayat (2) dan ayat (3) Pasal 8 diubah, sehingga berbunyi sebagai berikut: ...

3. dan seterusnya ...

Dengan model perubahan demikian masyarakat akan mengalami kesulitan memaknai secara utuh tanpa disediakan kodifikasi dan unifikasi peraturan yang ada. Pemahaman sepotong-sepotong ini akan berdampak pada potensi masalah seperti yang telah diuraikan sebelumnya.

\section{e. Omnibus Law}

Definisi Omnibus Law dari kata Omnibus yang berasal dari bahasa Latin yang maknanya untuk semuanya. Dalam Black Law Dictionary Ninth Edition oleh Bryan A.Garner disebutkan omnibus : relating to or dealing with numerous object or item at once; inculding many thing or having varius purposes, dimana artinya berkaitan dengan atau berurusan dengan berbagai objek atau item sekaligus; termasuk banyak hal atau memiliki berbagai tujuan. Oleh Prof. 
Satjipto Rahardjo ${ }^{17}$ sebagaimana dikutip oleh Agnes ${ }^{18}$ disebutkan bila digandeng dengan kata Law yang maka dapat didefinisikan sebagai hukum untuk semua. Dalam kajian hukum di Amerika, omnibus law dikenal dengan omnibus bill dan merupakan kebebasan dalam membentuk suatu peraturan dari legislatif. Para anggota bebas menentukan cara untuk menentukan suatu tujuan dan cara apapun bisa dilakukan agar cara tersebut tercapai ${ }^{19}$.

Model omnibus law sendiri dalam Undang-Undang 12/2011 beserta perubahannya belum memiliki format yang baku dan belum ada konsep Omnibus Law Sebagai salah satu asas dalam sumber hukum ${ }^{20}$. Akan tetapi dalam format UU Cipta Kerja (UU tersebut menggunakan metode Omnibus Law), yakni dipersamakan dengan kombinasi antara pembentukan Peraturan Baru dan Perubahan.

Dari sisi peraturan baru, UU Cipta Kerja memiliki judul dan batang tubuh seperti pembentukan peraturan baru pada teknik penyusunan Peraturan Perundang-undangan yang ada pada lampiran II UU 12/2011. Akan tetapi dalam pasal-pasalnya yang menyasar perubahan ataupun pencabutan undang-undang lain, formatnya identik dengan format batang tubuh dalam perubahan peraturan pada teknik penyusunan Peraturan Perundang-undangan yang ada pada lampiran II UU 12/2011.

Dampak dari bentuk model omnibus law ini juga sangat rawan untuk sulit dipahami masyarakat seperti peraturan perubahan. Selain model peraturan yang belum dibakukan, tapi juga menyasar banyak undang-undang yang sangat sulit dipahami masyarakat awam apabila tidak dilakukan kodifikasi dan unifikasi.

\footnotetext{
${ }^{17}$ Satjipto Rahardjo, 'Hukum, Masyarakat \& Pembangunan', Bandung: Alumni, 1981.

${ }^{18}$ Agnes Fitryantica, 'Harmonisasi Peraturan Perundang-Undangan Indonesia Melalui Konsep Omnibus Law', Gema Keadilan, 6(3), 2019, 300-316

DOI:https://doi.org/https://doi.org/10.14710/gk.6.3.300-316.

${ }^{19}$ Arif Hidayat, Zaenal Arifin, Politik Hukum Legislasi Sebagai Socio-Equilibrium Di Indonesia, Jurnal Ius Constituendum 4(2), 2019. http://dx.doi.org/10.26623/jic.v5i1.2117

${ }^{20}$ Suwandi Arham and Ahmad Saleh, 'Omnibus Law Dalam Perspektif Hukum Indonesia', Jurnal PETITUM 7(2), 2019, 72-81.

DOI:https://doi.org/https://doi.org/10.36090/jh.v7i2\%20Oktober.652.
} 


\section{Indikasi kebutuhan Hukum terhadap Pengaturan Kodifikasi dan Unifikasi}

Hukum dibutuhkan manusia sebagai salah satu bentuk usaha untuk menjaga atau menciptakan keadaan yang tertib, dan menjaga ketenteraman. ${ }^{21}$ Terciptanya keadaan yang demikian itu dipengaruhi oleh variabel pokok, berikut ${ }^{22}$ :

a. Adanya seperangkat kaidah yang terorganisasi ke dalam suatu sistem;

b. Adanya proses yang dinamakan sosialisasi;

c. Adanya proses yang dinamakan proses kontrol sosial.

Variabel inilah yang sering kali pada prakteknya tidak tersampaikan kepada masyarakat secara utuh yang akhirnya membuat masyarakat tidak berhasil terpenuhi kebutuhan hukumnya. Terutama dalam memahami peraturan perubahan dan peraturan yang menggunakan metode omnibus law yang belum dilakukan kodifikasi dan unifikasi.

Padahal sebagaimana diungkapkan oleh lawrence M. Friedman ${ }^{23}$ yang dikutip oleh Yudho dan Tjandrasari ${ }^{24}$, Efektivitas hukum itu sangat dipengaruhi oleh komponen struktural, komponen substansi dan komponen hukum yang ada sebagai berikut:

a. Komponen struktural, yakni lembaga-Iembaga pembuat undang-undang, pengendalian dan berbagai badan yang diberi wewenang untuk menerapkan hukum dan penegak hukum.

b. Komponen substansi, yakni kaidah-kaidah yang berlakunya tidak ditujukan kepada orang-orang atau pihak-pihak tertentu, akan tetapi kepada siapa saja yang dikenai perumusan kaidah umum.

c. Komponen kultural, yakni Sikap-sikap dan nilai-nilai dari masyarakat. Apakah masyarakat akan memanfaatkan lembaga pengadilan atau tidak dalam berbagai kasus dipengaruhi oleh sikap-sikap dan nilai-nilai yang dinamakan budaya hukum (legal culture).

Untuk komponen Struktural negara telah memiliki perangkat lembagalembaga yang tersistematis untuk melaksanakan suatu sistem hukum. Begitu juga

${ }^{21}$ Winarno Yudho and Heri Tjandrasari, 'Efektivitas Hukum Dalam Masyarakat', Jurnal Hukum \& Pembangunan 17(1), 2017, 57 DOI:https://doi.org/10.21143/jhp.vol17.no1.1227.

${ }^{22}$ Yudho and Tjandrasari. 44.

${ }^{23}$ Lawrence M Friedman, 'Legal Culture and Social Development', Law and Society Review, 1969, 29-

${ }^{24}$ Yudho and Tjandrasari. 
komponen Kultural, masyarakat indonesia memiliki adat istiadat yang tunduk pada aturan adat, agama, kesopanan, kesusilaan, dan Norma Hukum. Masalahnya sekarang adalah pada Komponen Substansi, dimana substansi hukum yang berbentuk norma perubahan dan metode omnibus law akan sulit dipahami oleh masyarakat jika tidak dilakukan kodifikasi dan unifikasi.

Inilah kebutuhan hukum yang saat ini dirasakan didalam masyarakat untuk memenuhi komponen substansi demi efektivitas hukum. Ketika kebutuhan tersebut dapat terpenuhi, komponen substansi tidak lagi penghambat terciptanya efektifitas hukum. Potensi yang mungkin terjadi jika kebutuhan hukum untuk kodifikasi dan unifikasi diterapkan adalah sebagai berikut:

a. Masyarakat mudah memahami peraturan, khususnya terhadap peraturan perubahan dan omnibus law;

b. Masyarakat akan lebih cerdas dan tidak mudah terpengaruh informasi yang tidak tepat terkait peraturan perubahan maupun omnibus law;

c. Masyarakat akan lebih kritis dalam pembentuk peraturan;

d. Meminimalisir Penyalahgunaan wewenang yang diawasi langsung oleh masyarakat yang dengan mudah memahami peraturan; dan

e. Potensi lain yang mendukung penyelenggara negara dalam memajukan kesejahteraan masyarakat.

Indikasi kebutuhan hukum terhadap pengaturan kodifikasi dan unifikasi ini telah tercermin secara jelas, sehingga lebih lanjut perlu secara jelas digambarkan bentuk kodifikasi dan unifikasi peraturan perubahan dan peraturan yang menggunakan metode omnibus law.

Setelah itu, diperlukan analisis penerapan pengaturan kodifikasi dan unifikasi peraturan perubahan dan peraturan yang menggunakan metode omnibus law agar penulisan ini dapat dijadikan dasar pertimbangan untuk pembentukan pengaturan kodifikasi dan unifikasi peraturan perubahan dan peraturan yang menggunakan metode omnibus law.

3. Gagasan Bentuk Kodifikasi dan Unifikasi Peraturan Perubahan dan Peraturan Omnibus Law 
Seperti yang telah diuraikan pada landasan teori peraturan perubahan dan omnibus law. Bentuk peraturan perubahan dan omnibus law yang terpisah dengan peraturan pokoknya memberikan kendala kepada masyarakat untuk memahami dengan mudah. Untuk itu bentuk kodifikasi dan unifikasi peraturan perubahan dan omnibus law harus memberikan kemudahan masyarakat untuk memahami.

Pada prinsipnya, bentuk kodifikasi dan unifikasi peraturan perubahan dan omnibus law dilakukan dalam bentuk 1 (satu) naskah yang dihimpun dari peraturan pokoknya dengan menambahkan peraturan perubahan dan omnibus law (meskipun berupa penambahan, perubahan, ataupun pencabutan).

Gagasan format kodifikasi dan unifikasi peraturan perubahan dan omnibus law dapat berbentuk sebagai berikut:

a. Judul

b. Pembukaan yang terdiri:

1) Frasa Dengan Rahmat Tuhan Yang Maha Esa

2) Jabatan Pembentuk Peraturan Perundang-undangan

3) Konsiderans

4) Dasar Hukum

5) Diktum

c. Batang Tubuh

1) Ketentuan Umum

2) Materi Pokok yang Diatur

3) Ketentuan Pidana (jika diperlukan)

4) Ketentuan Peralihan (jika diperlukan)

5) Ketentuan Penutup

d. Penutup

e. Penjelasan (jika diperlukan)

f. Lampiran (jika diperlukan)

Penjelasan:

a. Judul 
Untuk judul, demi memudahkan masyarakat memahami peraturan perubahan dan omnibus law sebaiknya dimuat dengan terlebih dulu memuat:

1) jenis,

2) nama peraturan,

3) frasa "dalam 1 (satu) naskah berdasarkan (dicantumkan peraturan pokok dan peraturan perubahannya)".

Contohnya sebagai beikut:

UNDANG-UNDANG REPUBLIK INDONESIA TENTANG

\section{PEMBENTUKAN PERATURAN PERUNDANG-UNDANGAN}

\section{DALAM 1 (SATU) NASKAH BERDASARKAN:}

1. Undang-Undang Republik Indonesia Nomor 12 Tahun 2011 Tentang Pembentukan Peraturan Perundang-undangan;

2. Undang-Undang Republik Indonesia Nomor 15 Tahun 2019 Tentang Perubahan atas Undang-Undang Republik Indonesia Nomor 12 Tahun 2011 Tentang Pembentukan Peraturan Perundang-undangan;

b. Pembukaan yang terdiri:

1) Frasa Dengan Rahmat Tuhan Yang Maha Esa

2) Jabatan Pembentuk Peraturan Perundang-undangan

3) Konsiderans Menimbang

Menggabungkan konsideran peraturan pokok dan peraturan perubahannya dengan memberikan penanda angka romawi.

Contoh:

Menimbang : I. a. bahwa untuk mewujudkan Indonesia sebagai negara hukum ... b. ...

II. a. bahwa pembangunan hukum nasional yang terencana, terpadu.. b. ...

4) Dasar Hukum Mengingat 
Menggabungkan dasar hukum mengingat hanya yang berbeda saja dengan memisahkan dengan menggunakan penomoran huruf kapital. Mengingat : A. 1. Pasal 20, Pasal 21, dan Pasal 22A Undang-Undang Dasar Negara Republik Indonesia Tahun 1945; 2....

B. 1. Undang-Undang Nomor L2 Tahun 2011 tentang Pembentukan Peraturan Perundang-undangan (Lembaran Negara Republik Indonesia Tahun 2011 Nomor 82, Tambahan Lembaran Negara Republik Indonesia Nomor 5234);

2. ...

5) Diktum

c. Batang Tubuh

Penulisan batang tubuh dilakukan penggabungan dari peraturan pokok dan peraturan perubahannya kedalam 1 (satu) naskah.

Contoh penggabungan UU 12/2011 dan UU 15/2019:

\section{Pasal 71}

(1) Pembahasan Rancangan Undang-Undang tentang Penetapan Peraturan Pemerintah Pengganti UndangUndang dilaksanakan melalui mekanisme yang sama dengan pembahasan Rancangan Undang-Undang.

(2)

\section{Pasal 71A}

Dalam hal pembahasan Rancangan Undang-Undang sebagaimana dimaksud dalam Pasal 65 ayat (1) telah memasuki pembahasan Daftar Inventarisasi Masalah pada periode masa keanggotaan DPR saat itu, hasil pembahasan Rancangan Undang-Undang tersebut disampaikan kepada DPR periode berikutrya dan berdasarkan kesepakatan DPR, Presiden, dan/atau DPD, Rancangan Undang-Undang tersebut dapat dimasukkan 
kembali ke dalam daftar Prolegnas jangka menengah dan/atau Prolegnas prioritas tahunan.

\section{Pasal 72}

d. Penutup

e. Penjelasan (jika diperlukan)

Mutatis mutandis dengan bentuk batang tubuh

f. Lampiran (jika diperlukan)

Mutatis mutandis dengan bentuk batang tubuh

Gagasan Bentuk kodifikasi dan unifikasi inilah yang nantinya akan digunakan untuk materi penyebarluasan sebagaimana diatur dalam UU 12/2011 BAB $\mathrm{X}$ tentang Penyebarluasan rancangan. Dengan demikian, hambatan komponen substansi agar dapat dipahami dengan mudah oleh masyarakat akan dapat dilaksanakan dengan baik.

\section{Gagasan Pengaturan Kodifikasi Unifikasi Peraturan Perubahan dan}

\section{Peraturan Omnibus Law}

Bentuk peraturan yang sudah diulas, untuk dapat diterapkan dan dilaksanakan harus masuk dalam pengaturan peraturan perundang-undangan. Idealnya bentuk kodifikasi dan unifikasi peraturan perubahan dan peraturan metode omnibus law masuk dalam pengaturan Lampiran II Undang-undang $12 / 2011$.

Akan tetapi sesuai dengan Pasal 64 perubahan Lampiran II Undang-undang 12/2011 sangat memungkinkan dengan menggunakan Peraturan Presiden baik dengan metode program penyusunan maupun izin prakarsa.

Setidaknya ada 2 (dua) Substansi yang memungkinkan untuk diatur adalah sebagai berikut:

1. kewajiban penyusun peraturan perubahan dan peraturan yang menggunakan metode omnibus law untuk membuat kodifikasi dan unifikasi dalam 1 (satu) naskah untuk memudahkan masyarakat.

2. memasukkan bentuk kodifikasi sebagaimana ulasan pada sub pembahasan. 
Dengan masuknya pengaturan tersebut, penyusun peraturan perubahan untuk membuat peraturan yang sudah dijadikan dalam 1 (satu) naskah untuk disebarluaskan dan dapat dipahami dengan mudah oleh masyarakat.

\section{E. PENUTUP}

Pengaturan kodifikasi dan unifikasi peraturan perubahan dan peraturan menggunakan metode omnibus law, sangat dibutuhkan untuk memenuhi komponen substansi peraturan yang dapat dengan mudah dipahami oleh masyarakat dengan menggunakan penghimpunan "Dalam 1 (satu) Naskah". Dengan demikian peraturan akan lebih mudah dipahami masyarakat. Bentuk Pengaturan kodifikasi dan unifikasi peraturan perubahan dan peraturan menggunakan metode omnibus law dapat menggunakan Peraturan Presiden sebagai dukungan penyebarluasan peraturan yang telah disusun. Hal ini sesuai dengan kewenangan yang diberikan dalam Pasal 64 UU 12/2011 yang merubah lampiran II dengan menggunakan Peraturan Presiden.

\section{DAFTAR PUSTAKA}

\section{Buku}

Friedman, Lawrence M, 'Legal Culture and Social Development', Law and Society Review, 1969.

Ibrahim, Johnny, 'Teori Dan Metode Penelitian Hukum Normatif', Malang: Bayumedia Publishing, 2005

Kansil, Cristine S T, and S T Christine, 'Kansil. Ilmu Negara (Umum Dan Indonesia)' (Jakarta: Pradnya Paramita, 2007)

Mukthie Fadjar, A, 'Tipe Negara Hukum', Banyumedia, Malang, 2005

Pound, Roscoe, and Marshall L DeRosa, An Introduction to the Philosophy of Law (Yale University Press, 1954), X

Rahardjo, Satjipto, 'Hukum, Masyarakat \& Pembangunan', Bandung: Alumni, 1981

Said, Umar, Pengantar Hukum Indonesia: Sejarah Dan Dasar-Dasar Tata Hukum Serta Politik Hukum Indonesia (Setara Press, 2009)

Sunggono, Bambang, 'Metode Penelitian Hukum', Radja Grafindo Persada, Jakarta, 1997

\section{Jurnal}

Arham, Suwandi, and Ahmad Saleh, 'Omnibus Law Dalam Perspektif Hukum Indonesia', Jurnal PETITUM 7(2), 2019.

DOI:https://doi.org/https://doi.org/10.36090/jh.v7i2\%20Oktober.652

Arif Hidayat, Zaenal Arifin, Politik Hukum Legislasi Sebagai Socio-Equilibrium Di Indonesia, Jurnal Ius Constituendum 4(2), 2019. 
http://dx.doi.org/10.26623/jic.v5i1.2117

Aulia, Eza, and Dara Quthni Effida, 'Kodifikasi Hukum Islam Di Indonesia Dalam Perspektif Kepastian Hukum', Ius Civile: Refleksi Penegakan Hukum Dan Keadilan, 2 (2), 2018.

Azhar, Muhammad 'Unifikasi Hukum Acara Pengujian Seluruh Peraturan Perundang-Undangan', Adminitrative Law \& Governance Journal 2(1), 2019. https://doi.org/10.14710/alj.v2i1.170-178

Fitryantica, Agnes, 'Harmonisasi Peraturan Perundang-Undangan Indonesia Melalui Konsep Omnibus Law’, Gema Keadilan 6(2), 2019.

DOI:https://doi.org/https://doi.org/10.14710/gk.6.3.300-316

Mulyani, Tri, and Dewi Tuti Muryati, 'Analisis Yuridis Mengenai Sistem Zonasi Dalam Penerimaan Peserta Didik Baru', Jurnal Usm Law Review 3(1), 2020. DOI: http://dx.doi.org/10.26623/julr.v3i1.2118

Paputungan, Merdiansa, 'Unifikasi Hukum Acara Pengujian Seluruh Peraturan Perundang-Undangan', Al-Qisth Law Review 1(1), 2018

Putra, Dewa Nyoman Rai Asmara, 'Asas Integrasi Dalam Undang-Undang Kepailitan Versus Cita-Cita Kodifikasi Dan Unifikasi Hukum Acara Perdata', Adhaper: Jurnal Hukum Acara Perdata 4(1), 2018.

Tomy Michael, Bentuk Pemerintahan Perspektif Omnibus Law, Jurnal Ius Constituendum 5(1), 2020. http://dx.doi.org/10.26623/jic.v5i1.1749

Setiyawan, Wahyu Beny Mukti, and Hadi Mahmud, 'Menggagas Model Restorative Justice Terhadap Tindak Pidana Marital Rape Dalam Membentuk Perlindungan Terhadap Perempuan Yang Sesuai Dengan Norma Hukum Di Indonesia', Jurnal Ius Constituendum 3(1), 2018. DOI: http://dx.doi.org/10.26623/jic.v3i1.864

Sugiantari, Anak Agung Putu Wiwik, 'Perkembangan Hukum Indonesia Dalam Menciptakan Unifikasi Dan Kodifikasi Hukum', Jurnal Advokasi, 5.2 (2015)

Yudho, Winarno, and Heri Tjandrasari, 'Efektivitas Hukum Dalam Masyarakat', Jurnal Hukum \& Pembangunan 17(1), 2017.

DOI:https://doi.org/10.21143/jhp.vol17.no1.1227

\section{Undang-Undang}

Undang-Undang Nomor 12 Tahun 2011 Tentang Pembentukan Peraturan Perundang-Undanngan

Undang-Undang Nomor 15 Tahun 2019 Tentang Perubahan atas Undang-Undang Nomor 12 Tahun 2011 Tentang Pembentukan Peraturan PerundangUndanngan

Undang-Undang Nomor 11 Tahun 2020 Tentang Cipta Kerja 